\title{
Pleural Fluid Amino-Terminal Brain Natriuretic Peptide in Patients With Pleural Effusions
}

\author{
Altug Cincin MD, Yasin Abul MD, Beste Ozben MD, Azra Tanrikulu MD, \\ Nurhayat Topaloglu MD, Gulsevil Ozgul MD, Sait Karakurt MD, and Ahmet Oktay MD
}

\begin{abstract}
BACKGROUND: Definite diagnosis of transudative or exudative pleural fluids often presents a diagnostic dilemma. The aim of this study was to evaluate whether amino-terminal brain natriuretic peptide (NT-proBNP) levels in pleural fluid has a diagnostic value for discriminating heart-failurerelated pleural effusions from non-heart-failure effusions. METHODS: Sixty-six subjects (40 male, mean age $61 \pm 18$ y) with pleural effusions were included. Samples of pleural fluid and serum were obtained simultaneously from each subject. Biochemical analysis, bacterial and fungal culture, acid-fast bacilli smear and culture, and cytology were performed on the pleural fluid. RESULTS: Subjects with heart-failure-related pleural effusion had significantly higher pleural NT-proBNP levels than other subjects $(P<.001)$. Pleural and serum NT-proBNP measures were closely correlated $(\mathrm{r}=0.90, P<.001)$. An NT-proBNP cutoff value of $\geq 2,300 \mathrm{pg} / \mathrm{mL}$ in pleural fluid had a sensitivity of $70.8 \%$, a specificity of $97.6 \%$, and positive and negative predictive values of $94.4 \%$ and $\mathbf{8 5 . 4 \%}$, respectively, for discriminating transudates caused by heart failure from exudates. Eight heart-failure subjects were misclassified as exudates by Light's criteria, 5 of whom received diuretics before thoracentesis. All misclassified subjects had pleural NT-proBNP levels higher than $1,165 \mathrm{pg} / \mathrm{mL}$, which predicted heart-failure-associated transudates with $95.8 \%$ sensitivity and $85.7 \%$ specificity. CONCLUSIONS: Pleural fluid NT-proBNP measurement in the routine diagnostic panel may be useful in differentiation of heart-failure-related pleural effusions and exudative pleural fluids with reasonable accuracy, especially in heart-failure patients treated with diuretics. Key words: amino-terminal brain natriuretic peptide; NT-proBNP; heart failure; Light's criteria; pleural effusion. [Respir Care 2013;58(2):313-319. (c) 2013 Daedalus Enterprises]
\end{abstract}

\section{Introduction}

Pleural fluid is classically classified as a transudate or an exudate, which helps in determining the cause of pleural effusions. The criteria of Light et al are used as a first step to differentiate transudates from exudates in the workup

Dr Cincin is affiliated with the Department of Cardiology, Bayburt Government Hospital, Bayburt, Turkey. Dr Abul is affiliated with the Department of Pulmonary Medicine, Faculty of Medicine, Karadeniz Technical University, Trabzon, Turkey. Drs Ozben and Tanrikulu are affiliated with the Department of Cardiology, Faculty of Medicine, Marmara University, Istanbul, Turkey. Dr Topaloglu is affiliated with the Pulmonary Medicine Clinics, Bolu Izzet Baysal Government Hospital, Bolu, Turkey. Dr Ozgul is affiliated with the Department of Biochemistry, Faculty of Medicine, Marmara University, Istanbul, Turkey. Dr Karakurt is affiliated with the Department of Pulmonary and Critical Care, Faculty of Medicine, Marmara University, Istanbul, Turkey. Dr Oktay is affiliated with the Cardiology Clinics, American Hospital, Istanbul, Turkey. of patients with pleural effusion. ${ }^{1}$ However, these criteria have some limitations, especially in patients with heart failure and taking diuretics. ${ }^{2,3}$ Imbalance of hydrostatic and osmotic forces caused by heart failure is the main reason that transudates and diuretic therapy limit the accuracy of the criteria, leading to misdiagnosis of pleural fluids. ${ }^{4,5}$ Misdiagnosis of transudates as exudates may lead to unwarranted invasive interventions or delay in the ini-

\footnotetext{
This work was partly supported by the Scientific Research Projects Commission, Marmara University, Istanbul, Turkey. The authors have disclosed no conflicts of interest.

Correspondence: Beste Ozben MD, Department of Cardiology, Faculty of Medicine, Marmara University, Yildiz Caddesi Konak Apartmani43/ 16, Besiktas 34353 Istanbul, Turkey. E-mail: bestes@ doctor.com.
}

DOI: $10.4187 /$ respcare. 01818 
tiation of appropriate therapy. Although clinical judgment can aid in determining which patients with pleural effusion most likely have heart failure, the criteria of Light et $\mathrm{al}^{1}$ are shown to be significantly superior to clinical presumption to separate heart-failure-associated transudates from exudates. $^{3}$ Thus, several other methods have been proposed to differentiate exudates from transudates, including the serum-effusion albumin difference (a difference of $<1.2 \mathrm{~g} / \mathrm{dL}$ between the serum and pleural fluid albumin levels), ${ }^{6}$ serum-effusion protein difference, pleural cholesterol concentration (pleural cholesterol $>60 \mathrm{mg} / \mathrm{dL}$ ), ${ }^{7}$ and pleural effusion/serum bilirubin ratio (a pleural fluid/ serum bilirubin ratio $>0.6) .{ }^{8}$ However, controversy exists as to which method is more accurate and effective.

Increased tension or stretching of the cardiac wall stimulates the synthesis and secretion of natriuretic peptides. The levels of both brain natriuretic peptide (BNP) and the amino-terminal proBNP (NT-proBNP) are significantly elevated in patients with heart failure. Thus, they are widely used in the diagnosis and management of heart failure. ${ }^{9-12}$ Recent studies demonstrated that BNP and NT-proBNP levels were elevated in the pleural fluid of patients with heart failure and suggested that pleural fluid NT-proBNP might be useful in the diagnosis of pleural effusion resulting from heart failure..$^{2,13,14}$

The aim of the study was to evaluate the diagnostic accuracy of pleural fluid NT-proBNP in differentiation of heart-failure-related pleural effusions from non-heart-failure-related effusions.

\section{Methods}

This investigation conformed to the principles outlined in the Declaration of Helsinki. The study was approved by the local ethics committee of Marmara University. All participants gave written informed consent before participating.

Seventy-five consecutive subjects with pleural effusions who were scheduled to undergo diagnostic thoracentesis were included prospectively into the study. The demographic and clinical parameters of the subjects were noted. Pleural fluid and serum samples were obtained simultaneously from each subject. Biochemical analysis (including lactate dehydrogenase ( $\mathrm{LDH})$, protein, albumin, glucose, blood urea nitrogen, and creatinine), bacterial and fungal culture, acid-fast bacilli smear, polymerase chain reaction test for Mycobacterium tuberculosis, and cytologic examinations were performed on all pleural fluid samples. Chest $\mathrm{x}$-ray and electrocardiography were obtained from each subject. All subjects underwent echocardiographic examination to determine biventricular systolic and diastolic functions, together with pulmonary hypertension and pericardial effusion, if present. Any further diagnostic test,

\section{QUICK LOOK}

\section{Current knowledge}

Pleural fluid is classically classified as a transudate or an exudate, which helps in determining the cause of effusions. The criteria of Light et al are used to differentiate transudates from exudates. Misdiagnosis of transudates as exudates may lead to unwarranted invasive interventions or delay in the initiation of appropriate therapy.

\section{What this paper contributes to our knowledge}

Plasma and pleural fluid amino-terminal brain natriuretic peptide (NT-proBNP) levels were significantly higher in patients with heart-failure-associated pleural effusion, compared to exudative pleural effusions. Measurement of NT-proBNP can improve accuracy in differentiating exudative and transudative pleural effusion.

such as pleural biopsy, was performed at the discretion of the primary physicians.

The diagnosis of heart failure was based on the presence of symptoms and signs, including paroxysmal nocturnal dyspnea, orthopnea, rales, jugular venous distention, third heart sound, prominent murmur, and pretibial edema. The diagnosis was further confirmed by echocardiography and chest $\mathrm{x}$-ray. Pleural effusion was attributed to heart failure when the subject had symptoms and signs of left ventricular failure, echocardiography study revealed systolic or diastolic dysfunction of the left ventricular, and the pleural effusion responded to appropriate diuretic therapy.

Measurement of NT-proBNP levels in serum and pleural effusion and all other biochemical analyses were carried out within 4 hours after specimen collection. NTproBNP levels were measured by a monoclonal electrochemiluminescence immunoassay using an immunoassay analyzer (Elecsys, Roche Diagnostics, Mannheim, Germany) according to the manufacturer's protocol. The test has an intra-assay coefficient of variation of $0.8-3 \%$. The detection range of the test is from 5 to $35,000 \mathrm{pg} / \mathrm{mL}$.

Pleural effusions were categorized as either exudates or transudates, according to the criteria of Light et $\mathrm{al}^{1}$ The fluid was defined as an exudate if it fulfilled at least one of the following criteria: pleural/serum ratio of total protein $>0.5$, pleural $/$ serum ratio of $\mathrm{LDH}>0.6$, or pleural $\mathrm{LDH}$ more than two thirds of upper normal limit of serum LDH.

Pleural effusions were diagnosed as malignant if malignant cells were detected on the cytologic examination of pleural fluid or pleural biopsy, or if the subject had a known malignancy and alternative diagnoses were excluded. Parapneumonic pleural effusion and empyema were defined as the clinical and radiological diagnosis of pneu- 


\section{Pleural Fluid Amino-Terminal Brain Natriuretic Peptide in Patients With Pleural Effusions}

Table 1. Blood and Pleural Fluid Characteristics of the Subjects

\begin{tabular}{|c|c|c|c|c|c|c|}
\hline & $\begin{array}{l}\text { Heart Failure } \\
\quad(n=21)\end{array}$ & $\begin{array}{l}\text { Malignant } \\
(n=22)\end{array}$ & $\begin{array}{l}\text { Parapneumonic } \\
\quad(n=8)\end{array}$ & $\begin{array}{l}\text { Empyema } \\
(n=7)\end{array}$ & $\begin{array}{l}\text { Tuberculosis } \\
\quad(n=5)\end{array}$ & $\begin{array}{l}\text { Others } \\
(n=3)\end{array}$ \\
\hline \multicolumn{7}{|l|}{ Blood } \\
\hline NT-proBNP, median (IQR), pg/mL & $6,653(2,324-21,869)$ & $136(51-392)$ & $671(266-2,105)$ & $198(123-1,583)$ & $68(43-216)$ & 2,568 \\
\hline Protein, mean $\pm \mathrm{SD}, \mathrm{g} / \mathrm{dL}$ & $6.7 \pm 1.1$ & $6.9 \pm 0.8$ & $6.7 \pm 1.1$ & $6.7 \pm 0.9$ & $7.0 \pm 1.0$ & $5.4 \pm 3.2$ \\
\hline $\mathrm{LDH}$, median (IQR), U/L & $390(316-536)$ & $400(313-572)$ & $436(263-598)$ & $326(253-413)$ & $298(243-986)$ & 472 \\
\hline \multicolumn{7}{|l|}{ Pleural } \\
\hline NT-proBNP, median (IQR), pg/mL & $7,583(1,883-16,085)$ & $279(110-452)$ & $814(465-2,135)$ & $498(98-1,107)$ & $202(81-409)$ & 3,961 \\
\hline Protein, mean $\pm \mathrm{SD}, \mathrm{g} / \mathrm{dL}$ & $3.3 \pm 1.8$ & $4.6 \pm 1.0$ & $3.6 \pm 2.2$ & $4.0 \pm 2.2$ & $5.1 \pm 1.3$ & $2.9 \pm 2.6$ \\
\hline LDH, median (IQR), U/L & $183(161-362)$ & $439(215-660)$ & $474(334-626)$ & $1,047(300-1,918)$ & $382(240-598)$ & 328 \\
\hline \multicolumn{7}{|l|}{ Pleural/Serum } \\
\hline Protein ratio, mean $\pm \mathrm{SD}$ & $0.49 \pm 0.21$ & $0.66 \pm 0.09$ & $0.49 \pm 0.32$ & $0.59 \pm 0.26$ & $0.72 \pm 0.11$ & $0.50 \pm 0.17$ \\
\hline $\mathrm{LDH}$ ratio, mean $\pm \mathrm{SD}$ & $0.58 \pm 0.36$ & $1.02 \pm 0.54$ & $1.49 \pm 1.43$ & $3.20 \pm 1.92$ & $1.09 \pm 0.74$ & $0.69 \pm 0.45$ \\
\hline Albumin difference, mean $\pm \mathrm{SD}, \mathrm{g} / \mathrm{dL}$ & $1.73 \pm 0.91$ & $1.11 \pm 0.37$ & $1.45 \pm 0.99$ & $1.34 \pm 0.96$ & $0.44 \pm 0.35$ & $2.53 \pm 1.37$ \\
\hline
\end{tabular}

monia or positive bacterial culture in pleural fluid, together with other suggestive laboratory findings (pleural fluid $\mathrm{pH}$ and white-blood-cell count, and blood whiteblood-cell count). Hepatic hydrothorax was defined as an effusion due to cirrhosis in the presence of ascites. Pleural fluid was categorized as tuberculous if Mycobacterium tuberculosis was found in pleural fluid, or granuloma in pleural biopsy, or an exudative lymphocytic effusion with high adenosine deaminase levels $(>40 \mathrm{U} / \mathrm{L})$ cleared in response to anti-tuberculosis therapy. Other miscellaneous causes of pleural effusions were determined by clinical and laboratory data by the attending physician.

Nine subjects with pleural effusions of undetermined origin, effusions with more than one possible cause, or hemothorax were excluded in the analyses.

\section{Statistical Analysis}

Statistical analysis was performed by a commercially available statistical software package (SPSS 16.0, SPSS, Chicago, Illinois). Data are presented as mean \pm SD. Because the blood and pleural fluid concentrations of NTproBNP and LDH were not normally distributed, their values are presented as median and IQR. The KruskalWallis test, Mann-Whitney U test, or Fisher exact test were used to assess the difference between different groups. The Spearman coefficient of rank correlation was used to evaluate the relation between NT-pro-BNP levels of plasma and pleural fluid. Receiver operating characteristic curve analysis was performed to determine the cutoff levels of pleural fluid NT-proBNP. A $P$ value of .05 or less was regarded as statistically significant.

\section{Results}

Sixty-six subjects (40 male) with pleural effusions who were scheduled for diagnostic thoracentesis were consecutively included in the study. The mean \pm SD and median age of the study group was $61 \pm 18$ years and 65 years. Twelve subjects had coronary artery disease, while 29 had hypertension, 11 had diabetes, and 12 had COPD. The causes of pleural effusions were as follows: malignancy 22 subjects $(33.3 \%)$, heart failure 21 subjects $(31.8 \%)$, parapneumonic 8 subjects (12.1\%), empyema 7 subjects (10.6\%), tuberculosis 5 subjects $(7.6 \%)$, renal disease 2 subjects $(3.1 \%)$, and liver cirrhosis 1 subject $(1.5 \%)$. Most subjects with malignancy-associated pleural fluid had either primary or metastatic lung cancer. Among the 21 subjects with heart failure, 5 subjects $(24 \%)$ had systolic heart failure, with a median left ventricular ejection fraction of $25 \%$, while the remaining $16(76 \%)$ had diastolic heart failure confirmed with echocardiography. Three subjects also had pericardial effusion, and 15 heart-failure subjects $(71 \%)$ had pulmonary hypertension, with a median systolic pulmonary arterial pressure of $45 \mathrm{~mm} \mathrm{Hg}$.

Blood and pleural fluid NT-proBNP levels are shown in Table 1, together with LDH and protein levels. Subjects with pleural effusion due to heart failure had significantly higher pleural fluid NT-proBNP levels than others $(P<.001)$ (Fig. 1). Pleural and serum NT-proBNP measures were closely correlated ( $\mathrm{r}=0.90, P<.001$, Fig. 2 ). While there were not any significant differences between blood and pleural total protein levels among the groups, the pleural LDH levels, pleural/blood LDH ratio, and serum-pleural fluid albumin difference significantly differed $(P=.04, P=.004$, and $P=.02$, respectively). 
Pleural Fluid Amino-Terminal Brain Natriuretic Peptide in Patients With Pleural Effusions

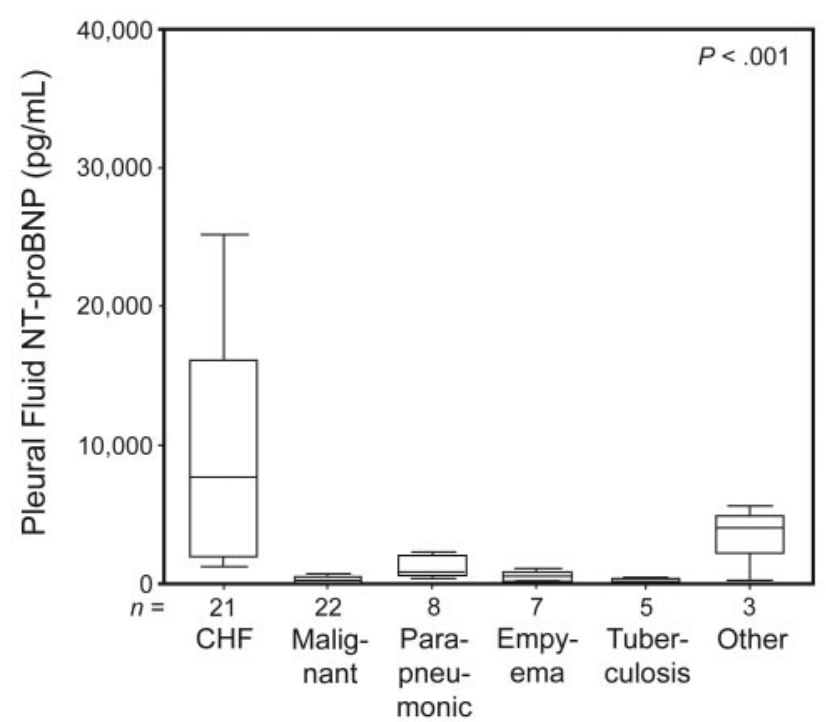

Fig. 1. The median and quartiles of pleural amino-terminal probrain natriuretic peptide (NT-proBNP) values according to etiology. $\mathrm{CHF}=$ congestive heart failure.

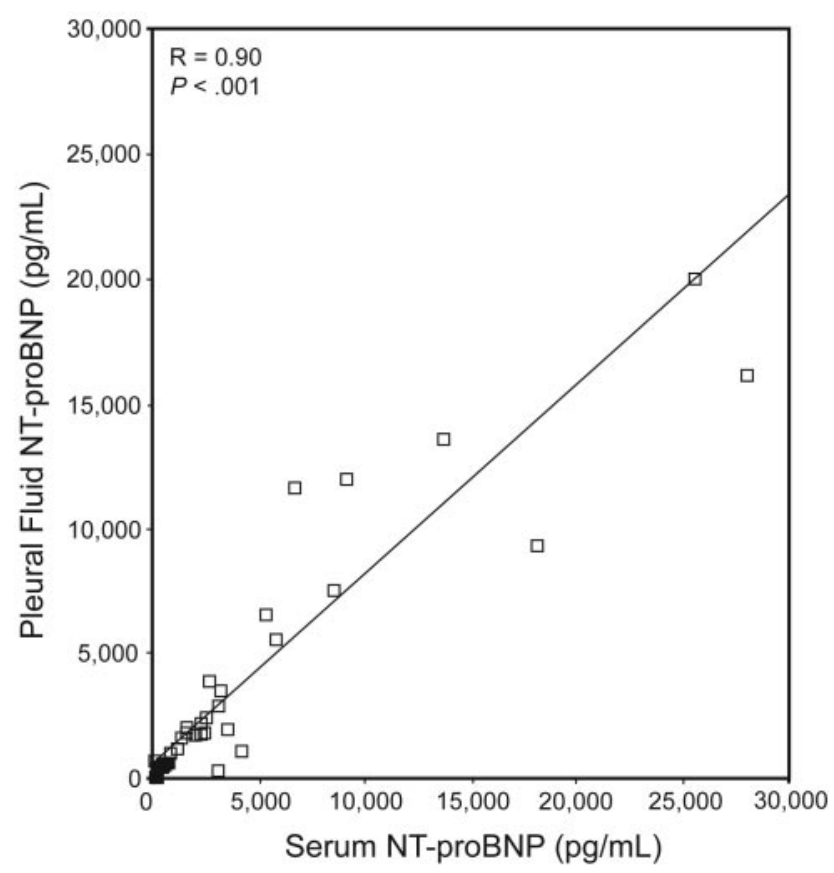

Fig. 2. Correlation of serum and pleural effusion level of aminoterminal pro-brain natriuretic peptide (NT-proBNP).

According to the criteria of Light et al, ${ }^{1} 51$ of the pleural fluids were exudates. The distribution of causes of pleural fluid according to transudate or exudate is presented in Table 2. Using the above criteria, 9 effusions were incorrectly classified as exudates (13.6\%). Eight of these subjects had pleural effusion due to heart failure, and one had renal failure. Pleural fluid and serum parameters of true transudates, false exudates, and true exudates are shown in
Table 2. Etiologies of Pleural Effusion, According to Transudate or Exudate, Defined by the Criteria of Light et al ${ }^{1}$

\begin{tabular}{lcc}
\hline \hline & $\begin{array}{c}\text { Transudate } \\
\text { (no.) }\end{array}$ & $\begin{array}{c}\text { Exudate } \\
\text { (no.) }\end{array}$ \\
\hline Malignant & 0 & 22 \\
Congestive heart failure & 13 & 8 \\
Parapneumonic & 0 & 8 \\
Empyema & 0 & 7 \\
Tuberculosis & 0 & 5 \\
Renal disease & 1 & 1 \\
Liver cirrhosis & 1 & 0 \\
Total & 15 & 51 \\
\hline
\end{tabular}

Table 3. The false exudates had significantly higher levels of pleural fluid and serum NT-proBNP compared to true exudates $(P<.001$ for both comparisons), while they had significantly lower levels of pleural fluid and serum NTproBNP, compared to true transudates $(P=.008$ and $P=.01$, respectively). Five of the false exudates received diuretics before thoracentesis, and the median level of pleural fluid NT-proBNP was $1,741 \mathrm{pg} / \mathrm{mL}$, while the serum NT-proBNP median level was $2,205 \mathrm{pg} / \mathrm{mL}$.

True transudates had a significantly higher serumpleural fluid albumin difference (see Table 3). The serumpleural fluid albumin difference $>1.2 \mathrm{~g} / \mathrm{dL}$ had a sensitivity of $66.7 \%$, a specificity of $67.6 \%$, and positive and negative predictive values of $52.2 \%$ and $79.3 \%$, respectively $(P=.02)$, while a serum-pleural fluid protein difference $>3.1 \mathrm{~g} / \mathrm{dL}$ had a sensitivity of $58.8 \%$, a specificity of $81.8 \%$, and positive and negative predictive values of $62.5 \%$ and $79.4 \%$, respectively $(P=.02)$ for discriminating transudates from exudates.

Receiver operating characteristic curve analysis (Fig. 3) demonstrated that an NT-proBNP cutoff value of $\geq 2,300 \mathrm{pg} / \mathrm{mL}$ in pleural fluid had a sensitivity of $70.8 \%$, a specificity of $97.6 \%$, and positive and negative predictive values of $94.4 \%$ and $85.4 \%$, respectively $(P<.001$, diagnostic accuracy $87.9 \%)$ for discriminating heart-failure-related transudates from non-heart-failurerelated pleural effusions. Table 4 gives detailed diagnostic information, including the appropriate decision statistics for the biochemical diagnosis of pleural effusions caused by heart failure. A pleural NT-proBNP cutoff value of $\geq 1,165 \mathrm{pg} / \mathrm{mL}$ in pleural fluid had a sensitivity of $95.8 \%$ for discriminating heart-failure-related effusions from exudates, with a specificity of $85.7 \%$, and 8 of the 9 subjects misdiagnosed as exudates had pleural fluid NT-proBNP levels higher than $1,165 \mathrm{pg} / \mathrm{mL}$.

\section{Discussion}

Our study showed that both plasma and pleural fluid NT-proBNP levels were significantly higher in subjects 


\section{Pleural Fluid Amino-Terminal Brain Natriuretic Peptide in Patients With Pleural Effusions}

Table 3. Pleural Fluid and Serum Parameters of True Transudates, True Exudates, and False Exudates

\begin{tabular}{|c|c|c|c|c|}
\hline & $\begin{array}{l}\text { True Transudates } \\
\quad(n=15)\end{array}$ & $\begin{array}{l}\text { False Exudates } \\
\quad(n=9)\end{array}$ & $\begin{array}{l}\text { True Exudates } \\
\quad(n=42)\end{array}$ & $P$ \\
\hline \multicolumn{5}{|l|}{ Blood } \\
\hline NT-proBNP, median (IQR), pg/mL & $8,502(5,357-25,625)$ & $2,442(1,206-3,339)$ & $177(72-631)$ & $<.001$ \\
\hline Protein, mean $\pm \mathrm{SD}, \mathrm{g} / \mathrm{dL}$ & $6.1 \pm 1.6$ & $7.1 \pm 1.3$ & $6.8 \pm 0.9$ & .26 \\
\hline $\mathrm{LDH}$, median (IQR), U/L & $456(287-604)$ & $459(380-497)$ & $393(283-535)$ & .51 \\
\hline \multicolumn{5}{|l|}{ Pleural } \\
\hline NT-proBNP, median (IQR), pg/mL & $11,620(5,654-19,983)$ & $2,024(1,435-3,199)$ & $367(127-623)$ & $<.001$ \\
\hline Protein, mean $\pm \mathrm{SD}, \mathrm{g} / \mathrm{dL}$ & $2.2 \pm 1.1$ & $4.5 \pm 1.8$ & $4.3 \pm 1.6$ & .003 \\
\hline LDH, median (IQR), U/L & $161(123-192)$ & $360(219-437)$ & $472(230-732)$ & .001 \\
\hline \multicolumn{5}{|l|}{ Pleural/Serum } \\
\hline Protein ratio, mean \pm SD & $0.37 \pm 0.12$ & $0.66 \pm 0.16$ & $0.62 \pm 0.20$ & .002 \\
\hline $\mathrm{LDH}$ ratio, mean $\pm \mathrm{SD}$ & $0.48 \pm 0.32$ & $0.79 \pm 0.37$ & $1.56 \pm 1.39$ & .001 \\
\hline Albumin difference, mean $\pm \mathrm{SD}, \mathrm{g} / \mathrm{dL}$ & $2.36 \pm 0.83$ & $1.09 \pm 0.71$ & $1.12 \pm 0.70$ & .001 \\
\hline
\end{tabular}

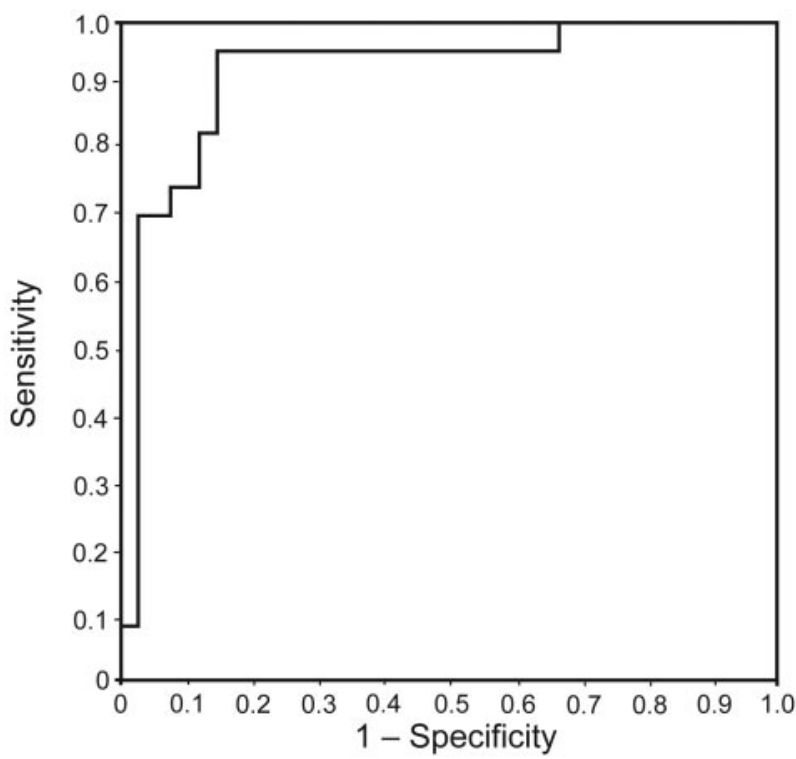

Fig. 3. Receiver operating characteristic curve of pleural fluid amino-terminal pro-brain natriuretic peptide (NT-proBNP) levels for differentiating true transudates from exudates. The area under the curve for pleural fluid NT-proBNP was 0.927 (95\% CI 0.856-0.997).

with heart-failure-associated pleural effusion, compared to others. Our results were in accordance with the recent studies that explored the diagnostic value of BNP and NT-proBNP in the etiology of pleural effusions..$^{2,15-20}$ Han et $\mathrm{al}^{2}$ measured pleural fluid and serum NT-proBNP levels in a consecutive series of 98 patients with heart failure and in 142 patients with other causes, and found that pleural fluid NT-proBNP levels among the heart-failure patients were significantly higher than others. Similarly, Porcel et al ${ }^{18}$ retrospectively examined 117 patients with pleural effusion and found that the pleural fluid levels of NTproBNP were significantly higher in patients with cardiac transudates than in patients with effusion of other causes. Tomcsányi et al ${ }^{15}$ measured NT-proBNP levels in the pleural effusion of 14 patients with heart failure and 14 patients with different pleural pathology and found that heart-failure patients had significantly higher levels of NT-proBNP.

The pleural fluid NT-proBNP or BNP cutoff values for discriminating pleural effusion with heart failure vary from $1,176 \mathrm{pg} / \mathrm{mL}$ to $4,000 \mathrm{pg} / \mathrm{mL} .^{7-11,13,14}$ Porcel et al ${ }^{18}$ found that pleural fluid NT-proBNP level $>1,500 \mathrm{pg} / \mathrm{mL}$ predicted pleural effusion associated with heart failure with $91 \%$ sensitivity and $93 \%$ specificity. Han et $\mathrm{al}^{2}$ reported that the pleural fluid NT-proBNP concentration of $1,714 \mathrm{pg} / \mathrm{mL}$ had a good accuracy (with $99 \%$ sensitivity and $99 \%$ specificity) for detecting heart-failure-associated transudate. Liao et al ${ }^{14}$ showed that the pleural fluid NTproBNP level of $\geq 2,220 \mathrm{pg} / \mathrm{mL}$ demonstrated a sensitivity of $100 \%$ and a specificity of $96.7 \%$ for the identification of heart failure. In our study we found that pleural fluid NT-proBNP level $\geq 2,300 \mathrm{pg} / \mathrm{mL}$ discriminated transudates caused by heart failure from exudates with $70.8 \%$ sensitivity and $97.6 \%$ specificity.

Tomcsányi et al ${ }^{15}$ showed that the criteria of Light et al ${ }^{1}$ had a sensitivity of $93 \%$ and specificity of $43 \%$ for transudates. However, the pleural fluid NT-proBNP accurately differentiated between the 2 groups. Han et $\mathrm{al}^{2}$ reported that 28 patients with pleural effusion due to heart failure were misclassified as exudates by the criteria of Light et al, ${ }^{1}$ and suggested that pleural fluid NT-proBNP levels identified 26 of them correctly. In our study 9 subjects out of 66 subjects (13.6\%) were misdiagnosed as exudates according to the criteria of Light et al. ${ }^{1}$ Pleural fluid NT- 
Table 4. Diagnostic Information for Pleural Fluid NT-proBNP Concentration in the Diagnosis of Pleural Effusion Caused by Heart Failure

\begin{tabular}{|c|c|c|c|c|c|}
\hline $\begin{array}{l}\text { Pleural Fluid NT-proBNP } \\
\text { Cut-off Values, pg/mL }\end{array}$ & $\begin{array}{c}\text { Sensitivity } \\
(\%)\end{array}$ & $\begin{array}{l}\text { Specificity } \\
(\%)\end{array}$ & $\begin{array}{c}\text { Positive Predictive } \\
\text { Value }(\%)\end{array}$ & $\begin{array}{c}\text { Negative Predictive } \\
\text { Value }(\%)\end{array}$ & $\begin{array}{c}\text { Diagnostic } \\
\text { Accuracy }(\%)\end{array}$ \\
\hline 1,165 & 95.8 & 85.7 & 79.3 & 97.3 & 89.4 \\
\hline 1,704 & 83.3 & 88.1 & 80.0 & 90.2 & 86.4 \\
\hline 2,000 & 75.0 & 92.9 & 85.7 & 86.7 & 86.4 \\
\hline 2,300 & 70.8 & 97.6 & 94.4 & 85.4 & 87.9 \\
\hline
\end{tabular}

proBNP levels of these 9 subjects were significantly higher than those of true exudates.

We preferred NT-proBNP measurement in our study. Porcel et al ${ }^{18}$ compared the diagnostic accuracy of pleural fluid NT-proBNP and BNP levels for diagnosing pleural effusions due to heart failure. They found that the areas under the curve for NT-proBNP and BNP were 0.96 and 0.90 , respectively, for diagnosing effusions due to heart failure. They also reported that age, sex, and serum creatinine level did not influence the NT-proBNP levels. They concluded that the pleural fluid NT-pro-BNP level was better than pleural BNP levels in establishing the diagnosis of heart-failure-associated effusions.

Diuretic treatment is a possible explanation for false exudates in heart-failure patients. Diuretics may change a transudate into an exudate by shifting fluid from the pleural space, which may elevate the levels of protein and LDH in the pleural fluid. ${ }^{2-4,21}$ Pleural fluid NT-proBNP is suggested to be useful in the diagnosis of pleural effusion resulting from heart failure, especially in patients with exudates who are treated with diuretics. Han et $\mathrm{al}^{2}$ reported that 26 of the 28 misclassified heart-failure patients received diuretics before thoracentesis and had pleural fluid NT-proBNP levels of higher than $1,714 \mathrm{pg} / \mathrm{mL}$. In our study, 5 of the false exudates $(55.6 \%)$ received diuretics before thoracentesis, and they all had pleural fluid NTproBNP levels higher than $1,165 \mathrm{pg} / \mathrm{mL}$.

We found a significant correlation between pleural fluid and serum NT-proBNP levels. Similarly, Han et $\mathrm{al}^{2}$ reported that pleural fluid NT-proBNP levels were well correlated with serum NT-proBNP levels $(\mathrm{r}=0.93, P<.001)$. The origin of NT-proBNP in pleural fluid is unclear. It has been suggested that it derives from serum NT-proBNP and might diffuse easily into the pleural space, due to its small molecular size.22 Thus, some authors suggest the use of plasma BNP concentrations as a diagnostic tool for determining the cardiac etiology of pleural effusions ${ }^{19}$ and note that there seems to be no additional value in measuring NT-proBNP in pleural fluid. ${ }^{17}$ Actually, a high serum NTproBNP level may even eliminate the need for diagnostic thoracentesis. But if a diagnostic thoracentesis is eventually to be done, pleural NT-proBNP may be measured alone, to confirm the diagnosis of heart-failure-associated pleural fluids.

\section{Study Limitations}

Our study has several potential limitations. First, this study was intended as a pilot study of using NT-proBNP in the diagnosis of pleural effusions. As a result, we limited our study population to patients with well defined causes of pleural effusion, thus excluding those in whom a definitive diagnosis could not be established. This design may somewhat cause overestimation of the receiver operating characteristic curves, but it is the first step in proving the validity of a diagnostic test. Additionally, we also excluded patients with effusions due to multiple etiologies. Heart failure is a frequent comorbidity in patients with pleural effusion, and it is essential to establish its role in pleural effusion. A future study with the inclusion of patients with effusions of multiple comorbidities may elucidate the diagnostic use of NT-proBNP in determining the role of heart failure in these patients. Second, given the limitations of low enrollment, we are currently not able to demonstrate to what extent pleural NT-proBNP concentration adds diagnostic information to the treating clinician's initial clinical impression. Finally, our study sample was limited in size and we could not adjust NT-proBNP concentrations, which were shown to be influenced by several factors, including age, sex, renal function, anemia, and obesity. ${ }^{23,24}$ Plasma concentrations of NT-proBNP are higher in elderly patients, females, and in patients with renal failure. However, in the study of Porcel et al ${ }^{18}$ age, sex, and serum creatinine level were not shown to influence the NT-proBNP levels. We believe that confirmation of our results and similar other studies in larger trials will yield accurate cutoff values for pleural NT-proBNP, and the simple test of pleural NT-proBNP determination may be routinely used in the differential diagnosis of pleural effusions.

\section{Conclusions}

NT-proBNP seems to be a reliable and accurate biomarker to diagnose patients with pleural effusion caused 


\section{Pleural Fluid Amino-Terminal Brain Natriuretic Peptide in Patients With Pleural Effusions}

by heart failure. The inclusion of pleural fluid NT-proBNP measurement in the routine diagnostic panel may enhance discrimination among the different causes of pleural effusions. The test may be useful in differentiation of heartfailure-related pleural effusions, especially in patients who have been treated with diuretics, and in this setting the pleural fluid NT-proBNP may be superior to the criteria of Light et $\mathrm{al}^{1}$ for discriminating heart-failure-related effusions.

\section{ACKNOWLEDGMENTS}

The authors thank Nural Bekiroglu PhD, Department of Biostatistics and Medical Informatics, Marmara University, Istanbul, Turkey, for review of the statistical analysis.

\section{REFERENCES}

1. Light RW, Macgregor MI, Luchsinger PC, Ball WC Jr. Pleural effusions: the diagnostic separation of transudates and exudates. Ann Intern Med 1972;77(4):507-513.

2. Han $\mathrm{CH}$, Choi JE, Chung JH. Clinical utility of pleural fluid NT-pro brain natriuretic peptide (NT-proBNP) in patients with pleural effusions. Intern Med 2008;47(19):1669-1674.

3. Romero-Candeira S, Hernández L, Romero-Brufao S, Orts D, Fernández C, Martín C. Is it meaningful to use biochemical parameters to discriminate between transudative and exudative pleural effusions? Chest 2002;122(5):1524-1529.

4. Romero-Candeira S, Fernández C, Martín C, Sánchez-Paya J, Hernández L. Influence of diuretics on the concentration of proteins and other components of pleural transudates in patients with heart failure. Am J Med 2001;110(9):681-686.

5. Burgess LJ, Maritz FJ, Taljaard JJ. Comparative analysis of the biochemical parameters used to distinguish between pleural transudates and exudates. Chest 1995;107(6):1604-1609.

6. Roth BJ, O'Meara TF, Cragun WH. The serum-effusion albumin gradient in the evaluation of pleural effusions. Chest 1990;98(3): 546-549.

7. Hamm H, Brohan U, Bohmer R, Missmahl HP. Cholesterol in pleural effusions. A diagnostic aid. Chest 1987;92(2):296-302.

8. Meisel S, Shamiss A, Thaler M, Nussinovitch N, Rosenthal T. Pleural fluid to serum bilirubin concentration ratio for the separation of transudates from exudates. Chest 1990;98(1):141-144.

9. McDonagh TA, Holmer S, Raymond I, Luchner A, Hildebrant P, Dargie HJ. NT-proBNP and the diagnosis of heart failure: a pooled analysis of three European epidemiological studies. Eur J Heart Fail 2004;6(3):269-273.

10. Knebel F, Eddicks S, Schimke I, Bierbaum M, Schattke S, Beling M, et al. Myocardial tissue Doppler echocardiography and $\mathrm{N}$-terminal
B-type natriuretic peptide (NT-proBNP) in diastolic and systolic heart failure. Cardiovasc Ultrasound 2008;6:45.

11. Lubien E, DeMaria A, Krishnaswamy P, Clopton P, Koon J, Kazanegra R, et al. Utility of B-natriuretic peptide in detecting diastolic dysfunction: comparison with Doppler velocity recordings. Circulation 2002;105(5):595-601.

12. Goetze JP, Mogelvang R, Maage L, Scharling H, Schnohr P, Sogaard $\mathrm{P}$, et al. Plasma pro-B-type natriuretic peptide in the general population: screening for left ventricular hypertrophy and systolic dysfunction. Eur Heart J 2006;27(24):3004-3010.

13. Porcel JM, Chorda J, Cao G, Esquerda A, Ruiz-González A, Vives M. Comparing serum and pleural fluid pro-brain natriuretic peptide (NT-proBNP) levels with pleural-to-serum albumin gradient for the identification of cardiac effusions misclassified by Light's criteria. Respirology 2007;12(5):654-659.

14. Liao H, Na MJ, Dikensoy O, Lane KB, Randal B, Light RW. Diagnostic value of pleural fluid N-terminal pro-brain natriuretic peptide levels in patients with cardiovascular diseases. Respirology 2008; 13(1):53-57.

15. Tomcsányi J, Nagy E, Somlói M, Moldvay J, Bezzegh A, Bózsik B, Strausz J. NT-brain natriuretic peptide levels in pleural fluid distinguish between pleural transudates and exudates. Eur J Heart Fail 2004;6(6):753-756

16. Porcel JM, Martínez-Alonso M, Cao G, Bielsa S, Sopena A, Esquerda A. Biomarkers of heart failure in pleural fluid. Chest 2009; 136(3):671-677.

17. Kolditz M, Halank M, Schiemanck CS, Schmeisser A, Höffken G. High diagnostic accuracy of NT-proBNP for cardiac origin of pleural effusions. Eur Respir J 2006;28(1):144-150.

18. Porcel JM, Vives M, Cao G, Esquerda A, Rubio M, Rivas MC. Measurement of pro-brain natriuretic peptide in pleural fluid for the diagnosis of pleural effusions due to heart failure. Am J Med 2004; 116(6):417-420.

19. Gegenhuber A, Mueller T, Dieplinger B, Lenz K, Poelz W, Haltmayer M. Plasma B-type natriuretic peptide in patients with pleural effusions: preliminary observations. Chest 2005;128(2):1003-1009.

20. Porcel JM. The use of probrain natriuretic peptide in pleural fluid for the diagnosis of pleural effusions resulting from heart failure. Curr Opin Pulm Med 2005;11(4):329-333.

21. Chakko SC, Caldwell SH, Sforza PP. Treatment of congestive heart failure. Its effect on pleural fluid chemistry. Chest 1989;95(4):798802 .

22. Zemans RL, Chatterjee K, Matthay MA. Diagnostic utility of B-type natriuretic peptide in patients with acute dyspnea or pleural effusions. Am J Med 2004;116(6):424-426.

23. Ordonez-Llanos J, Collinson PO, Christenson RH. Aminoterminal pro-B-type natriuretic peptide: analytic considerations. Am J Cardiol 2008;101(3A):9-15.

24. Rehman SU, Januzzi JL Jr. Natriuretic peptide testing in clinical medicine. Cardiol Rev 2008;16(5):240-249. 